\title{
Development of General Chemical Teaching Materials (Stoichiometry) in an Integrated Network of Media- Based Higher Order Thinking Skills
}

\author{
Jamalum Purba ${ }^{1, *}$ Freddy Tua Musa Panggabean ${ }^{1}$ Adi Widarma ${ }^{2}$ \\ ${ }^{1}$ Department of Chemistry Education, Faculty of Mathematics and Natural Sciences, Universitas Negeri Medan, Jl. \\ Willem Iskandar Pasar V, Medan, Indonesia \\ ${ }^{2}$ Department of Electrical Engineering, Faculty of Engineering Universitas Negeri Medan, Jl. Willem Iskandar Pasar \\ $V$, Medan, Indonesia \\ ${ }^{*}$ Corresponding author. Email: jamalum@unimed.ac.id
}

\begin{abstract}
21st century education is becoming increasingly important to ensure learners have learning and innovating skills, skills using technology and information media. One of the skills of the 21 st century is learning and innovating skills including high-level thinking skills. The object of this study was the development of teaching materials in the general chemical network of HOTS-based media-based stoichiometry materials, designed to be accessible to students online as well as improve students' high-level thinking skills. Through this HOTS-based media integrated online teaching material, students are trained to think critically, creatively, analytically about the information and data available in solving problems, as well as independent teaching materials that students can learn anytime and anywhere. The teaching materials products in the HOTS-based media integrated network developed have been declared valid and proven effective in improving students' high-level thinking skills in stoichiometry materials.
\end{abstract}

Keywords: HOTS, Teaching materials, Stoichiometry, Integrated network, HOTS-based media.

\section{INTRODUCTION}

The principle of 21 st century learning uses a learnercentered learning approach in which teachers and lecturers act as facilitators. The quality of an education also always refers to the results or academic achievements achieved by learners, where good quality of education is the goal of education itself. The results of the International Programme for International Student Assessment (PISA) study showed the achievements of reading literacy, mathematical literacy, and scientific literacy achieved by Indonesian students are very low and can only occupy the bottom 10 from 65 countries. Trends in International Mathematics and Science Study (TIMSS) shows Indonesian students are ranked very low in the ability (1) to understand complex information, (2) theory, analysis and problem solving, (3) the use of tools, procedures and problem solving, and (4) conduct investigations [1].

Of course, there are many factors that cause the low results of pisa studies and one of the contributing factors is because students in Indonesia are poorly trained in solving contextual questions, demanding reasoning, argumentation and creativity in solving them, where the questions are characteristic of TIMS questions. Various efforts have been made by the government to address the problem including efforts to improve the curriculum to curriculum 2013. One of the efforts in improving the 2013 Curriculum is the improvement of assessment standards, by gradually adapting the international standard assessment model. Improved assessment of learning outcomes is expected to help students to improve high-level thinking skills (HOTS) and is expected to encourage students to think broadly and in depth about learning materials. HOTS is part of Bloom's taxonomy of revisions in the form of operational verbs consisting of analysis (C4), evaluation (C5) and creative (C6) that can be used in the preparation of questions.

Higher Order Thinking Skill (HOTS) is a high level of thinking skills that demand critical, creative, analytical thinking, information and data in solving problems [3]. High-level thinking is a type of thinking that tries to explore questions about existing knowledge regarding 
issues that are not clearly defined and do not have a definite answer [4].

Low levels of thinking ability are not only experienced by students at the school level, but this is also the case for students in college. The results of the initial study, which researchers conducted, found that there are still many new students whose high level of thinking skills are still low including in general chemistry courses. As a result of the researchers' analysis, most students still find it difficult to solve HOTS questions on the C4-C6 indicator. Each individual's high level of thinking ability certainly varies depending on the exercises often performed to develop it. In addition to the use of strategies or learning models by teachers / lecturers, other factors that also determine the success of learners in learning are teaching materials that students use as learning resources. Supporting the implementation of an effective learning process, cannot be separated from the use of teaching materials. Teaching materials that can be used by students as a source of self-learning have an important role in improving and developing their highlevel thinking skills. Teaching materials can be packaged in printed and non-printed form [5].

An educator including lecturers are also required to be able to design teaching materials that are oriented to active student engagement and are expected to stimulate students to be able to think high levels. It is also in accordance with the concept of 21 st century education, namely century skills, scientific approach, authentic learning, and authentic assessment. One of the skills of the 21 st century is learning and innovation skills that are able to think creatively, work creatively, and create new innovations. When students are directed to be able to think critically and creatively means students are targeted to have a high level of thinking skills. The development of appropriate teaching materials and in accordance with the needs of students is the best effort to be able to improve the achievement of student academic achievement and foster high-level thinking skills of students. To produce a good quality of teaching equipment or materials, the teaching materials must be prepared and planned carefully to produce a good learning activity.

In addition to the use of teaching materials as a learning resource for students, another factor that also needs to be considered by a lecturer is the use of innovative and constructive learning media in reconstructing students' knowledge, abilities and creativity. The development of information technology and communication in today's digital era seems unstoppable. Today the world has entered the digitalbased 4.0 industry where technology has become the most basic thing and brings the current generation into the world of digital literacy that has fused with the current state of society. This condition makes the community easier, faster and has a greater chance of finding various information and able to overcome the limitations of space and time.

In the era of industrial revolution 4.0, various human resources in all fields are required to have digital skills especially in the field of education. Various technologies should already be applicable in classroom learning activities. An educator, both teachers and lecturers, needs to plan innovative and creative strategies, teaching materials and learning media by utilizing technologybased learning. One of the media that can be applied in the learning process is Adobe Flash and Articulate Story Line (online-based) media.

The use of computer media (multimedia) can be an alternative because it can integrate molecular animation and video demonstrations [6]. The development of technology triggered the rapid development of elearning, a wide variety of software or programs that have been provided for learning media that can be accessed at any time and all places. The development of e-learning triggered the creation of interactive learning media [7]. One of the most supportive software in its application as an interactive learning medium is Adobe Flash CS6 which has all multimedia elements so that it can be used to the maximum to improve the learning process and student achievement. This Adobe Flash CS6 application is a medium that contains elements of motion, images, and sound. For example, in the form of presentation media, interactive media [9]. The use of interactive learning media with Adobe Flash CS6 can be an alternative learning medium and able to make learning more varied, attract students' learning interests, and get a positive response from students [7], it is expected that students can directly see simulations/images that resemble the actual phenomenon, so that students are able to understand at once [10].

The Media Articulate Story Line can also be developed into a learning medium to overcome students' difficulties in learning [11], can be developed to attract students' attention [12], arouse motivation and stimulate students to learn, provide an integral or comprehensive experience from concrete to abstract. Articulate Storyline is software that functions as a medium of communication or presentation. Learning media using this software is no less interesting than other interactive media. Articulate Storyline is an advanced software that can build interactive e-learning modules. Articulate Storyline's look is similar to PowerPoint but offers more perks [15].

Based on the phenomenon and description above, it is necessary to develop teaching materials in an integrated network of media based on Higher Order Thinking Skills (HOTS) in general chemistry courses that are expected to support the implementation of effective and optimal learning processes. Teaching materials that need to be developed in the form of digital books in the network that integrated media Adobe Flash and Articulate Story Line 
(based online) based higher order thinking skills (HOTS) in the course of General Chemistry.

\section{METHODS}

This research includes a type of research and development (R\&D) that is a type of research that produces products instead of testing a theory. Research and development is a process used to develop and validate educational products [16], test the effectiveness of those products [17], and be accountable [18]. The result of this development research is teaching materials in network or digital book integrated media (Adobe Flash and Articulate Story Line) based higher order thinking skills (HOTS) in the course of General Chemistry Stoichiometry materials.

The development model used refers to the ADDIE development model. The procedure is carried out through several stages, including: (a) Analysis, (b) Design, (c) Development (d) Implementation, and (e) Evaluation. Techniques and instruments used in this study include: interviews, validation sheets and tests. Interviews are used for data collection when conducting research as preliminary study materials to look for problems to be researched. Interviews are also used in product trials both at the time of validation to experts and product trials in the field as consideration in the improvement of developed teaching materials. Validation sheets are used to obtain data on the validation results of experts on hotsbased media integrated teaching materials developed. The results of the expert validator assessment will be tested for feasibility or validity. The test instruments are prepared to obtain data on the high level of thinking ability (HOTS) of students. Tests are compiled and developed according to HOTS indicators including $\mathrm{C} 4$, C5 and C6.

The data of the research results are analyzed gradually to determine the feasibility (validity) and effectiveness of teaching materials in the developed network. Expert validation data is analyzed taking into account feedback, comments, and suggestions from validators. The results of the analysis served as a guideline to revise the teaching materials developed. The validity of the teaching materials that have been created can be seen from the validation sheet filled by the expert validator and the results of the Q\&A during the validation process. The effectiveness of the teaching materials products developed was obtained from the results of the student's high-level thinking ability (HOTS) test. Test the effectiveness of the developed teaching materials analyzed from hots enhancement with t-test or paired approach of t-test samples with the help of SPSS program.

\section{RESULTS AND DISCUSSION}

\subsection{Validation results of teaching materials in the network}

The validity (feasibility) of the materials developed is validated by 3 expert validators. The results of expert validators on teaching materials in the Stoichiometry material network obtained an average total score of 4.22 or declared valid. In terms of eligibility the content obtained an average score of 4.28 (valid); on the aspect of presentation eligibility obtained an average score of 4.20 (valid); on the aspect of language eligibility obtained an average score of 4.22 (valid); and in the graphing aspect obtained an average score of 4.18 (valid).

Table 1 Validation results of teaching materials in the stoichiometry.

\begin{tabular}{|c|c|c|c|c|c|}
\hline \multirow{2}{*}{$\begin{array}{l}\text { Aspects of } \\
\text { assessment }\end{array}$} & \multicolumn{3}{|c|}{$\begin{array}{c}\text { Validator (mean } \\
\text { score) }\end{array}$} & \multirow{2}{*}{$\begin{array}{l}\text { Total } \\
\text { mean }\end{array}$} & \multirow[t]{2}{*}{ Criteria } \\
\hline & $\mathbf{I}$ & II & III & & \\
\hline $\begin{array}{l}\text { Content } \\
\text { eligibility }\end{array}$ & 4.25 & 4.42 & 4.17 & 4.28 & Valid \\
\hline $\begin{array}{l}\text { Presentation } \\
\text { eligibility }\end{array}$ & 4.10 & 4.30 & 4.20 & 4.20 & Valid \\
\hline $\begin{array}{l}\text { Language } \\
\text { eligibility }\end{array}$ & 4.00 & 4.44 & 4.22 & 4.22 & Valid \\
\hline Graphworthiness & 4.00 & 4.27 & 4.27 & 4.18 & Valid \\
\hline Mean tot & valid & ion & & 4.22 & Valid \\
\hline
\end{tabular}

\subsection{HOTS-based media validation results on material aspects}

The validity (feasibility) of HOTS-based media developed on material aspects is validated by 2 expert validators. The results of the material expert validator on HOTS-based media Stoichiometry material obtained an average total score of 4.20 or declared valid. In terms of scope and depth of material obtained an average score of 4.22 (valid); on the aspect of accuracy of presentation (systematic) and not misconceptions on the material obtained an average score of 3.94 (quite valid); on the aspect of conformity and clarity of animation on the material obtained an average score of 3.89 (quite valid); on the aspect of clarity of the formula on the material obtained an average score of 4.11 (valid); on the accuracy aspect of the sample of the problem in each learning activity obtained an average score of 4.50 (valid); on the accuracy of the answer to the evaluation question in each learning activity obtained an average score of 4.00 (valid); on the assessment aspect HOTS obtained an average score of 4.70 (valid). 
Table 2 Hots-based media validation results on the aspects of assessment.

\begin{tabular}{|c|c|c|c|c|}
\hline \multirow[t]{2}{*}{ Aspects of assessment } & \multicolumn{2}{|c|}{ Validator (mean score) } & \multirow{2}{*}{$\begin{array}{l}\text { Total } \\
\text { mean }\end{array}$} & \multirow{2}{*}{ Criteria } \\
\hline & $\mathrm{I}$ & II & & \\
\hline Scope and depth of material & 4.11 & 4.33 & 4.22 & Valid \\
\hline $\begin{array}{l}\text { Accuracy of presentation (systematic) is not a } \\
\text { misconception on the material }\end{array}$ & 3.67 & 4.22 & 3.94 & Valid enough \\
\hline Conformity, clarity of animation on the material & 3.56 & 4.22 & 3.89 & Valid enough \\
\hline Clarity of formulas on materials & 4.00 & 4.22 & 4.11 & Valid \\
\hline $\begin{array}{l}\text { Accuracy of sample questions in each learning } \\
\text { activity }\end{array}$ & 4.00 & 5.00 & 4.50 & Valid \\
\hline $\begin{array}{l}\text { Accuracy of the answer to the evaluation question in } \\
\text { each learning activity }\end{array}$ & 4.00 & 4.00 & 4.00 & Valid \\
\hline HOTS Rating & 4.40 & 5.00 & 4.70 & Valid \\
\hline Mean total validation & & & 4.20 & Valid \\
\hline
\end{tabular}

\subsection{HOTS-based media validation results on media aspects}

The validity (feasibility) of HOTS-based media developed on the media aspect is validated by 3 expert validators. The results of the media expert validator on HOTS-based media Stoichiometry material obtained an average total score of 4.09 or declared valid. On the software engineering aspect obtained an average score of 4.07 (valid); on the aspect of the interface display obtained an average score of 4.15 (valid); and on the visual communication aspect obtained an average score of 4.04 (valid). Overall, the assessment results by expert validators on the media aspect concluded that HOTSbased media on developed Stoichiometry materials is considered valid (table 3).

Table 3 Hots-based media validation results on the aspects of assessment.

\begin{tabular}{lccccc}
\hline \multicolumn{1}{c}{$\begin{array}{c}\text { Aspects of } \\
\text { assessment }\end{array}$} & \multicolumn{3}{c}{$\begin{array}{c}\text { Validator (mean } \\
\text { score) }\end{array}$} & $\begin{array}{c}\text { Total } \\
\text { mean }\end{array}$ & Criteria \\
\cline { 2 - 4 } & I & II & III & & \\
\hline $\begin{array}{l}\text { Software } \\
\text { engineering }\end{array}$ & 4.20 & 3.70 & 4.30 & 4.07 & Valid \\
$\begin{array}{l}\text { Interface } \\
\text { display }\end{array}$ & 4.00 & 4.22 & 4.22 & 4.15 & Valid \\
$\begin{array}{l}\text { Visual } \\
\text { communication }\end{array}$ & 4.13 & 4.00 & 4.00 & 4.04 & Valid \\
\hline \multicolumn{3}{c}{ Mean total validation } & & 4.09 & Valid \\
\hline
\end{tabular}

\subsection{Product effectiveness}

The effectiveness of teaching materials products in the integrated network of HOTS-based media developed is analyzed based on the improvement of learning results obtained by students in completing hots tests on Stoichiometry materials using pre-test - post-test design. The test was conducted to one sample group of 30 students without any comparison (control) samples. Test results are analyzed with t-test or paired approach of ttest samples with the help of SPSS program. Early HOTS students on Stoichiometry materials before being given teaching materials in an integrated network of HOTSbased media produced (Pre-test) obtained an average score of 59.87 and standard deviation of 5.606 with the lowest score of 48 and the highest score of 60 . After the action through learning using teaching materials in the integrated network of HOTS-based media from the results of post-test obtained an average student HOTS score of 87.20 and standard deviation of 8.142 with the lowest score of 72 and the highest score of 96 . T-test results with a paired approach of t-test samples obtained a tcount value of 18.387 with a probability of $0.000<$ 0.05 (table 4).

Table 4 Product effectiveness results (t-test).

\begin{tabular}{|c|c|c|c|c|c|c|}
\hline & & Mean & $\begin{array}{c}\text { Std. } \\
\text { Deviation }\end{array}$ & $\mathbf{t}$ & df & $\begin{array}{c}\text { Sig. } \\
\text { (2- } \\
\text { tailed) }\end{array}$ \\
\hline $\begin{array}{l}\text { Pair } \\
1\end{array}$ & $\begin{array}{l}\text { Post- } \\
\text { test } \\
- \\
\text { pre- } \\
\text { test }\end{array}$ & 27.333 & 8.142 & 18.387 & 29 & 0.000 \\
\hline
\end{tabular}

The results of the product effectiveness analysis in table 4, concluded that the application of teaching materials in the integrated network of HOTS-based media developed on Stoichiometry materials is effective in improving student HOTS. The effectiveness of the use of HOTS-based media integrated teaching materials developed in Stoichiometry materials was $45.6 \%$.

The results of the development research obtained material products in the integrated network of Adobe Flash media and Articulate Story Line based hots that are declared valid (feasible) and effective in improving HOTS students in general chemistry courses stoichiometry materials. Validity (eligibility) is qualitatively fulfilled based on the assessment (validation) of expert validators who are overall declared in the valid category.

The effectiveness of teaching materials products in hots-based media integrated network is fulfilled based on the implementation of teaching materials in hots-based 
media integrated network that can be accessed by students online and evidenced by the improvement of students' ability to complete HOTS instruments on Stoichiometric materials with the results of t-test analysis of 18.387 and $p=0,000$ so that it is concluded that the application of teaching materials in the network of integrated HOTS-based media is valid and effective $d$ nature increases student HOTS.

The results of the implementation of teaching materials in the network of integrated media based on HOTS are also proven to improve student HOTS. Before being given teaching materials from the results of student pre-tests on Stoichiometry materials obtained an average initial HOTS score of 59.87 students and after the learning action using teaching materials in the integrated network of HOTS-based media on Stoichiometry materials from the results of Post-test obtained the average value of student HOTS of 87.20 with an average difference of HOTS value of 27.33 as well as the magnitude of effectiveness or increase of student HOTS on Stoichiometric material after given teaching materials in the integrated network of HOTS-based media is $45.6 \%$.

This has implications that to improve the capabilities of HOTS students can be done by developing innovative teaching materials integrated with HOTS-based media that can be accessed and downloaded online as teaching materials or self-learning resources for students. Through teaching materials in the integrated network of HOTSbased media is expected to help improve the understanding, mastery and capabilities of HOTS students because through this online teaching materials integrated hots-based media, students are trained to think critically, creatively, analytically to the information and data that exist in solving problems, and can repeat the material anytime and anywhere because it can be accessed and downloaded by students on the e-learning site of the department of chemistry education, faculty of mathematics and natural sciences, Universitas Negeri Medan.

\section{CONCLUSION}

This research and development resulted in teaching materials in an integrated network of HOTS-based media on Stoichiometry materials through the ADDIE development model. Teaching materials are developed and designed in an integrated manner with HOTS-based media that train students to think critically, creatively, analytically about information and data to solve problems in teaching materials and developed media. Hots-based media integrated teaching materials produced can also be accessed online students on the e-learning site of the department of chemistry education, faculty of mathematics and natural sciences, Universitas Negeri Medan. Teaching materials in the integrated network of HOTS-based media developed have been declared valid and proven effective in improving students' HOTS capabilities.

\section{REFERENCES}

[1] Depdiknas, Kurikulum 2013, Departemen Pendidikan Nasional, Jakarta, 2013.

[2] M.Z. Fanani, Strategi Pengembangan Soal Higher Order Thinking Skills (HOTS) dalam Kurikulum 2013, Edudeena, vol. 2, 2018, pp. 57-76. DOI: https://doi.org/10.30762/ed.v2i1.582

[3] C. Barrat, Higher Order Thinking And Assessment, International Seminar on current issues in Primary Education: Prodi PGSD Universitas Muhammadiyah Makasar, 2014.

[4] Y. Haig, Higher Order Thinking And Assessment, International Seminar on current issues in Primary Education: Prodi PGSD Universitas Muhammadiyah Makasar, 2014.

[5] Y. Nalarita, T. Listiawan, Pengembangan E-Modul Kontekstual Interaktif Berbasis WEB Pada Mata Pelajaran Kimia Senyawa Hidrokarbon, Jurnal Ilmiah Multitek Indonesia, vol. 12, 2018, pp. 85-94. DOI: http://dx.doi.org/10.24269/mtkind.v12i2.1125

[6] Y.R. Salesah, M. Amir, R. Qadar, Pengembangan Multimedia Interaktif Berbasis Adobe Flash Cs6 Professional Pada Pembelajaran Kesetimbangan Kimia, Jurnal Kimia dan Pendidikan Kimia, vol. 2, 2017, pp. 80-89.

[7] M. Busiri, Suparji, Pengembangan Media Pembelajaran Interaktif dengan Menggunakan Adobe Flash CS6 Pada Mata Diklat Rencana Anggaran Biaya (Rab) di SMK Negeri 2 Surabaya, Jurnal Kajian Pendidikan Teknik Bangunan, vol. 3, 2015, pp. 81-91.

[8] M.M. Romadhon, Sutopo, Pengembangan Media Pembelajaran Teknik Pemesinan Frais Berbasis Adobe Flash Cs6, Jurnal Pendidikan Vokasional dan Teknik Mesin, vol. 5, 2017, pp. 139-144.

[9] I.Z. Fauziah, Sutrisno, Suwarni, Pengembangan EModul Berbasis Adobe Flash CS6 pada Mata Pelajaran Penataan Barang Dagang, Jurnal Pendidikan Bisnis dan Manajemen, vol. 2, 2016, pp. 154-159.

[10] J. Sianturi, F.T.M. Panggabean, Implementasi Problem Based Learning (PBL) menggunakan Virtual dan Real Lab Ditinjau dari Gaya Belajar Untuk Meningkatkan Hasil Belajar Siswa, Jurnal Inovasi Pembelajaran Kimia (Journal of Inovation in Chemistry Education), vol. 1, 2019, pp. 58-63. DOI: https://doi.org/10.24114/jipk.v1i2.15460 
[11] R.A. Pratama, Media Pembelajaran Berbasis Articulate Storyline 2 Pada Materi Menggambar Grafik Fungsi di SMP PATRA DHARMA 2 Balik Papan, Jurnal DIMENSI, vol. 7, 2018, pp. 19-35. DOI: https://doi.org/10.33373/dms.v7i1.1631

[12] Darnawati, Jamiludin, L. Batia, Irawaty, Salim, Pemberdayaan Guru Melalui Pengembangan Multimedia Pembelajaran Interaktif Dengan Aplikasi Articulate Storyline, Jurnal Pengabdian Kepada Masyarakat, vol. 1, 2019, pp. 8-16.

[13] F.A. Candra, E. Ismayati, Pengembangan Media Pembelajaran Kemagnetan Listrik Berbasis Computer Based Instruction (CBI) di SMK NU 1 Sukodadi Lamongan, Jurnal Pendidikan Teknik Elektro, vol. 7, 2018, pp. 71-77.

[14] S.I. Purnama, B.I.G.P. Asto, Pengembangan Media Pembelajaran Interaktif Menggunakan Software Articulate Storyline pada Mata Pelajaran Teknik Elektronika Dasar Kelas X TEI 1 Di SMK Negeri 2 Probolinggo, Jurnal Pendidikan Teknik Elektro, vol. 3, 2014, pp. 275-279.

[15] P.S. Pambudi, P. Sujatmiko, D. Pambudi, Pengembangan Media Pembelajaran Matematika Berbasis Video Tutorial Dalam Program Komputer Pada Materi Trigonometri Kelas X IPS SMA Negeri 6 Surakarta, Jurnal Pendidikan Matematika, vol. 3, 2019, pp. 265-274. DOI: https://doi.org/10.20961/jpmm\%20solusi.v3i3.383 29

[16] P. Setyosari, Metode Penelitian Pendidikan dan Pengembangan, Kencana Prenada Media Group, Jakarta, 2013.

[17] Sugiyono, Metode Penelitian Pendidikan Pendekatan Kuantitatif, Kualitatif, dan R\&D, Alfabeta, Bandung, 2013.

[18] N. Saodih, Metode Penelitian Pendidikan, Remaja Rosdakarya, Bandung, 2010. 